\title{
Factors Affecting the Choice of Science Subjects among Female Students in Jigawa Metropolis, Nigeria
}

\author{
Azubuike Adams ${ }^{1}$, Azubuike Amarachi Salome ${ }^{2}$ \\ ${ }^{1}$ Biological Science Department, Nigeria Police Academy, Kano, Nigeria \\ ${ }^{2}$ School of Education, Jigawa State College of Education, Gumel, Nigeria \\ Email: ${ }^{*}$ dr.azubuikeadams@yahoo.com
}

Received 18 June 2014; revised 20 July 2014; accepted 3 August 2014

Copyright (C) 2014 by authors and Scientific Research Publishing Inc.

This work is licensed under the Creative Commons Attribution International License (CC BY). http://creativecommons.org/licenses/by/4.0/

c) (i) Open Access

\section{Abstract}

The work is to investigate the factors affecting the choice of science subjects among female students at the senior secondary level in Jigawa metropolis. There are factors that influence the choice of science subject among female students. Some of the factors are the sex of the students, peer group influence, motivation and the choice of a future career. In order to analyze some of these factors and their effect on female students in Jigawa metropolis, questionnaires were administered to female school of SS II and SS III in some randomly selected secondary schools. The hypothesis were tested; the use of data obtained from the questionnaires administered; and results presented in Tables 6-9.

\section{Keywords}

Science Subjects, Female Students, Questionnaires, Respondents

\section{Introduction}

In the early civilization, citizens were educated informally, usually within the family unit. Education simply means learning to live. As civilization become more complex, however, education became formally structured. The comprehensive initial effort of the ancient Chinese and Greek societies concentrated solely on the education of males. The post baby Ionian Jews and Plato were exception to this pattern. Plato was apparently the first significant advocate of women education (Compton's Encyclopedia, 1988).

In the late 1950s, the world entered the science age with the Russian launching of "spuntnik" as a result of

*Corresponding author. 
this new enthusing for science and technology in the 1960s. Scientist in the United State of America and elsewhere launched elementary science programmed for primary schools in 1960s. A group of educators and scientist in Nigeria started a similar program with ancient on local material and improvised equipments such as jam jars, bamboo-microscope and bamboo cage. The program later spread to other parts of the country (Fafunwa, 1974).

Over the years, many science curricula programmes have been developed for both primary and secondary levels usage. For example, primary had developed over the years through programmes such as African primary science programme (A.P.S.P), the NERC primary science, mathematics project and the federal government corecurriculum development project in primary science. Integrated science was introduced in Nigeria through the Ayetoro basic science scheme and the science teacher associate of Nigeria (STAN). In fact, the introduction of integrated science into secondary education reflects a new world-wide dimension to the teaching of science.

Despite the emphasis on the study of science in Nigeria, it is sedding to realize that the country is not making any significant headway and is still besieged with technological problems. Besides, there have been problems of unified language. For the reasons of lack of technological awareness to sexes, unemployment, illiteracy etc., Nigeria has been grouped among the "third world" countries of the world (Fafunwa, 1974).

To solve this problem, there is emphasis on the study of science and technology in school so as to meet up with power needs of the country. In fact, government took a stand that admission of students into higher institutions must be in ratio of 60:40 for science and art subjects respectively this so because science and technology have become an integral part of the world culture. It is almost impossible today to live a satisfactory life without the knowledge of science. Nigeria therefore need to develop her human and natural resources to solve her problems such as improving her transport systems, developing her mineral resources, controlling her soil erosion, introducing modern scientific measures and controlling disease, etc.

In the opinion of Debay (1980), the state of science and technology in the country is now a matter of great concern. This arises the increasing realization that Nigeria cannot develop rapidly as its intends without creating an adequate scientific and technological man power at all levels of working population. Debay went further to suggest that the nation should train adequate scientist and technicians for rapid development in technology.

Barn (1979), "Nigeria cannot increase her productivity on the farm, industries and factories without science and technology". He added it will amount to self deception and avoiding realities to import machines and experts. Science is the nucleus for technological development. As a result, the teaching of science subjects should be given greater emphasis so that this country can have a large number of science graduates irrespective of the gender.

In fact, there is need for more females in medicine especially in the field of gynecology, which deals with women anatomy. More females are needed in engineering, pharmacy, piloting, radiography, etc. in which the females are currently very few (STAN publication 2000). The low percentage of female students in these areas can be attributed to their choice of subjects at the secondary level and improper guidance in subjects' selection.

Akinmuwagun (1996). In Nigeria, the percentage of females in secondary school has increased steadily over the years, as many Nigerian almost the geographical regions of the country have come to realize the importance of girls' education and the percentage of young girls offering science subjects in senior secondary schools throughout the country has continued to increase.

Akinmuwagun (1996). During adolescent years pressure to conform to stereotypical female gender roles causes negative effects on girls in some physical science subjects, making them reluctant to volunteer for experimental work while taking in lesson. In spite of this, it has been indicated that the percentage of young girls offering science in secondary school in Nigeria increased by about 25\% between 1990 and 1996. This trend is not different in Jigawa state where the number of the female students offering science subjects in both public and private schools has also increase appreciably between 1980 and 1999, by over 60\% (Barn, 1999). This was a result of innovative measures by successive government, such as the establishment of girls science secondary schools.

Akinmuwagun (1996) equally carried out a survey on factors affecting the choice of Biology among student in Jigawa city. However, as a result of the interrelationship among sciences, there is clear need to expand the scope of his work and to embrace not only biology but the entire science fields, since science is a correlation of subject and to investigate analytically the factors affecting the choice of science subjects in both the public and private schools in Jigawa metropolis (Adeyemi, 1985). 


\subsection{Statement of the Problems}

There are many factors which assumed to be influencing the choice of science subjects among female students, some of which are the sex of the students, peer group influence, motivation and the choice of future career. It is the objective of this work research to investigate those factors that affect the choice of science subjects among female students in secondary schools in rural and urban metropolis. In the process, answers would be sought to the following questions.

1) Does the sex of the students have any influence on the choice of science subjects in Jigawa metropolis?

2) Does the availability of laboratory facilities have any influence on the choice of science subjects among female students in Jigawa metropolis?

3) Does the sex of the teachers teaching the science have any significant effect on the interest of female students in science?

4) What are the effects of peer group and parents on females attitude on the choice of science subjects in Jigawa metropolis?

5) Does the choice of future career have any effect on the choice of science subjects among female students in Jigawa metropolis?

\subsection{Purpose of the Study}

This work is directed toward the identification of factors which are directly responsible for the choice of science subjects among female students in selected school in Jigawa metropolis. The finding of this work will attempt to:

1) Identify some problems hindering the choice of science subjects among female students in Jigawa metropolis.

2) Suggest various ways of increasing participation of female students in science subjects.

3) Suggest various ways of promoting science education in Jigawa state in general.

\subsection{Significant of the Study}

Nigeria as a developing country, lay more emphasis on the advancement of science and technology. In order to attain a remarkable high in this area appropriate attention must be given to the science subjects like Biology, Physics, and Chemistry, etc., in our secondary schools. Female students should be encouraged and solutions to the problems facing female students in choosing the science subjects in senior secondary schools must be addressed.

For a developing country like Nigeria, need for science subjects cannot be undermined. There is need for competent scientist both in quality and quantity to confront these challenges. It is disappointing to the note that inspite of high population of females in the state (census, 1991), their enrolment in secondary schools in Jigawa state is not encouraging which affects the national development (Barn, 1999).

This may be attributed to our inability to properly identify the factors militating against her choice of science subjects by female students. This work therefore, highlight some factors against the choice of science subjects among female students in secondary school in Jigawa metropolis with a view to solve such problems, thus increasing the number of female students studying sciences. Finally, the findings of this work will serve as an incentive and reference materials for anyone wishing to embark on a similar work.

\subsection{Hypothesis}

1) The sex of science teachers does not have any significant influence on the choice of science subjects among female students in Jigawa metropolis.

2) The availability of competent and qualified teachers does not have any influence on the choice of science subjects among female students in Jigawa metropolis.

3) Availability of laboratory equipment/apparatus and practical science activities do not have influence on the choice of science subjects among female students in Jigawa metropolis.

\subsection{Scope of the Study}

The scope of the work is only restricted to the factors affecting the choice of science subject among female stu- 
dents in Jigawa metropolis, because there are about seven (7) registered secondary schools out of these, five (5) secondary schools (two privates and three public schools) were selected for the purpose of data collection. The names of the schools are as follows: Salem Group of School, Dutse Capital School, Dutse Model International, Government Girl Science Secondary School, Government Girls Arabic Secondary School.

\section{Materials and Methods}

It is apparently clear that various factors are responsible for choosing science subject among female science students nationwide. This work seeks to investigate, through direct questions and guided response, some of the factors responsible for the choice of science among female students in Jigawa metropolis.

\subsection{Research Design}

This work is designed to investigate the factors affecting the choice of science subjects among female students in Jigawa metropolis Jigawa state. In the process answer would be sought to the following questions:

1) Does the sex of the students have an influence on the choice of science subjects among female student in Jigawa metropolis?

2) Does the availability of laboratory facilities have any influence on the choice of science subjects among female students in Jigawa metropolis?

3) Does the sex of the teachers teaching the science subjects have any significant effect on the interest of female students in science?

4) What are the effects of peer group and parent on female attitude to the choice of science subjects in Jigawa metropolis?

5) Does the choice of future career have any effect on choice of science subjects among female students in Jigawa metropolis?

\subsection{Research Procedure}

The procedure for this work includes:

1) Surveying available data.

2) Constructing questionnaire: In drawing the questionnaire, possible answers were provided from which the respondent were expected to choose from the questions were very direct in order to facilitate easy understanding.

3) Validating questionnaire: To ensure that valid and reliable questionnaire was constructed.

4) Administering questionnaire: The questionnaire was administered to female students of SS II and SS III in selected school.

5) Data collection, treatment and analysis: Percentages were calculated on the answer given by the respondents to each question on the questionnaire.

\subsection{Research Sample}

The population of this work comprises the secondary school in Jigawa metropolis. The selection of schools was done randomly. A total of four hundred and forty-five (445) questionnaires were issued out of which four hundred and twenty-one (421) were properly completed and returned. So that we used 70 questionnaire respondents in each school for complete the questionnaire. In each school, SS II and SS III female students were used for the sampling. The sample was made up of science and non science students.

The selection of the schools was based on criteria. The schools chosen are spread all over the metropolis. The schools also have provision for common subjects or the same type of the subjects is offered in the school certificate examination. All selected schools are approved by West African Examination Council (WAEC) in the mixed schools the questionnaires were administered to only females, as the research is more concern about them.

\subsection{Research Instrument and Data Collection}

The main instrument for the work is the questionnaire. The questionnaire was aimed and eliciting a specific information on female students enrolment in science subjects. The questionnaire contained questions and items each of which has a four part rating scale of strongly agree, agreed, disagreed and strongly disagreed. 
The question was administered to the students with the help of the class teachers. The questions were answered individually without discussion between students and without stating their names. Respondent were instructive on how to answer the question and further explanation given by the researcher on the purpose of the study were necessary to remove all doubts.

The questionnaire was distributed to the students after the researcher had established a cordial relationship with the students. The students were given enough time to answer the questions in addition to earlier instrument and explanation in case of any difficulty or uncertainty on the part of the respondents.

\subsection{Method of Data Analysis}

In order to analyze the data obtained from the research questions and hypothesis, the frequencies and mean of the response made by the respondents to each question on the questionnaire and the various percentages were calculated. The data collected from administration of the research questionnaire will be translated in to meaningful statistics. Percentages will be used to identify the meaningful information out of the collected data from the questionnaire.

A total of four hundred and forty-five (445) questionnaire were issued, out of which four hundred and twentyone (421) were properly completed and returned. That represents about $95 \%$ of the total number of questionnaires issued to the various schools. The questionnaires returned to the researcher were conveniently utilized for the analysis.

\section{Results}

Various statistical methods have been used to present the data collected, which are inform of tables and percentages. Each piece of information was compared to enable the reader to determine the factors which affect the choice of science subject among female students in Jigawa metropolis. This is done in such away as to enable the reader to compare, contrast and evaluate the data collected so as to confirm or reject the formulated hypothesis? Thus, the responses were represented in the tables below Tables 1-9.

Table 1 shows that $18 \%$ of the respondents believed that science is for males, while $83 \%$ of the respondents disagree with this notion, $42 \%$ of the respondents agreed that usually females do better in art and social science subjects while $58 \%$ disagreed, $21 \%$ of the respondents believed that girls are more interested in science that boys while $76 \%$ does not agreed that. Then $60 \%$ of the respondents believed that boys are more interested than girls while $40 \%$ do not share this believe.

Table 1. (a) Showing the selected schools; (b) Response to a questionnaire statement on influence of the sex of the students on the choice of science subjects among female students in Jigawa metropolis.

(a)

\begin{tabular}{cccc}
\hline S/N & Names of Schools & Status & Type \\
\hline 1. & Dutse Model International & Private school & Mixed \\
2. & Salem High of School & Private school & Mixed \\
3. & Dutse Capital Sec. Sch. & Private school & Mixed \\
4. & Govt. Girls Arabic Sec. Sch & Govt. School & Females \\
5. & Govt. Day Senior Sec. Sch. & Govt. School & Females \\
6. & Govt. Day Senior Sec. Sch Takur & Govt. School & Females \\
\hline
\end{tabular}

(b)

\begin{tabular}{|c|c|c|c|c|c|}
\hline \multirow[t]{2}{*}{ Statement on Questionnaire } & \multicolumn{2}{|c|}{ Responses } & \multirow[t]{2}{*}{ Total } & \multicolumn{2}{|c|}{ Percentage } \\
\hline & Agree (A) & Disagree (D) & & Agree (A) & Disagree (D) \\
\hline I believed that science is for males & 76 & 344 & 420 & $18 \%$ & $83 \%$ \\
\hline Females usually do better in art and social subjects & 176 & 243 & 419 & $42 \%$ & $58 \%$ \\
\hline Girls are more interested in the sciences than boys & 91 & 324 & 415 & $21 \%$ & $76 \%$ \\
\hline Boys are more interested in science than girls & 251 & 167 & 418 & $60 \%$ & $40 \%$ \\
\hline
\end{tabular}


From the result in Table 1, it can be confirm that sex of the students does not have any significant influence no choice of science among female students in Jigawa metropolis

It can be seen from Table 2 above that, $65 \%$ of the respondents choose science subjects because the science laboratories in their school are well equipped, $35 \%$ of the respondents however, did not agree with this notion. It is obvious from the responses that the choice of science subjects among females students in Jigawa metropolis was influence by how well equipped the science laboratories in sample schools are.

Table 3 shows that $45 \%$ of the respondents were of the notion that the female science teachers in their school are very good teachers, while about $55 \%$ believed to the contrary. Also $68 \%$ of the respondents do not even have any female science teacher in their schools, while $37 \%$ of the respondents however did not agree with this notion.

It can be agreed on a general basis the sex of teacher does not significantly influence the choice of science subject among female students in Jigawa metropolis.

Table 4 shows that $86 \%$ of the respondents were not influenced to choose science subjects because most of their friends choose to offer the science while $14 \%$ of the respondents were influenced by their friends or fear to choose science subjects. Also from Table 4, it can be seen that $84 \%$ of the respondents choose the science out of their personal aspiration while, $11 \%$ agreed that their choice of science was not their personal decision. Furthermore $20 \%$ of the respondents agreed that their choice of science is the decision of $t$ heir parents while $82 \%$ believed that their parents did not influence their decision to choose the science subjects.

Based on the result, it can be deducted that peer group and parental influence did not play a significant role in the choice of science subjects among female students in Jigawa metropolis, as indicated in Table 4.

Table 5 shows that $93 \%$ of the respondents agreed that their choice of a future career greatly influenced their choosing of the science while $7 \%$ opine that their choice of future career has no influence on the choice of science subjects as indicated in Table 5.

Table 6 shows that $54 \%$ of the respondents agreed that their choice of science subjects because the teachers teaching them the science subject are quite competent while $44 \%$ for the respondents, however, did not agree with this notion. It is fact and clearly seen from the response of the students above, the presence of competent and qualified female have a significant influence on the choice of science subjects among female students in Jigawa metropolis as shown in Table 6.

Table 2. It shows the influence of the availability of laboratory facilities on the choice of science subjects.

\begin{tabular}{cccccc}
\hline Statement on Questionnaire & \multicolumn{2}{c}{ Responses } & Total & \multicolumn{2}{c}{ Percentage } \\
\hline & Agree (A) & Disagree(D) & & Agree (A) & Disagree (D) \\
\hline $\begin{array}{c}\text { I choose science subjects because the science } \\
\text { laboratories in my school are well equipped }\end{array}$ & 274 & 145 & 419 & $65 \%$ & $35 \%$ \\
\hline
\end{tabular}

Table 3. It represents the influence of the sex of the teacher teaching the sciences.

\begin{tabular}{|c|c|c|c|c|c|}
\hline \multirow{2}{*}{ Statement on Questionnaire } & \multicolumn{2}{|c|}{ Responses } & \multirow{2}{*}{ Total } & \multicolumn{2}{|c|}{ Percentage } \\
\hline & Agree (A) & Disagree (D) & & Agree (A) & Disagree (D) \\
\hline $\begin{array}{l}\text { The female science teachers in my school are very } \\
\text { good teachers }\end{array}$ & 188 & 231 & 419 & $45 \%$ & $55 \%$ \\
\hline In my school there is no female science teacher & 264 & 157 & 421 & $68 \%$ & $32 \%$ \\
\hline
\end{tabular}

Table 4. It shows the effects of peer group and parental influence on females’ attitudes to the choice of science subjects.

\begin{tabular}{|c|c|c|c|c|c|}
\hline \multirow{2}{*}{ Statement on Questionnaire } & \multicolumn{2}{|c|}{ Responses } & \multirow{2}{*}{ Total } & \multicolumn{2}{|c|}{ Percentage } \\
\hline & Agree (A) & Disagree (D) & & Agree (A) & Disagree (D) \\
\hline $\begin{array}{l}\text { I choose science subjects because most of my } \\
\text { friends offer sciences subjects }\end{array}$ & 56 & 363 & 419 & $14 \%$ & $86 \%$ \\
\hline $\begin{array}{l}\text { The female science teachers in my school are } \\
\text { very good teachers }\end{array}$ & 350 & 50 & 400 & $84 \%$ & $11 \%$ \\
\hline $\begin{array}{c}\text { In my school there is no female science } \\
\text { teacher }\end{array}$ & 84 & 340 & 424 & $20 \%$ & $82 \%$ \\
\hline
\end{tabular}


Table 5. It shows the influence of choice of a future career on the choice of science subjects among female students.

\begin{tabular}{|ccccccc}
\hline \multirow{2}{*}{ Statement on Questionnaire } & \multicolumn{2}{c}{ Responses } & \multirow{2}{*}{ Total } & \multicolumn{2}{c}{ Percentage } \\
\cline { 2 - 3 } & Agree (A) & Disagree (D) & & Agree (A) & Disagree (D) \\
\hline $\begin{array}{c}\text { My choice of science subjects is as a result } \\
\text { of my future career }\end{array}$ & 390 & 30 & 420 & $93 \%$ & $7 \%$ \\
\hline
\end{tabular}

Table 6. It shows the influences of the availability of competent and qualified teachers on the choice of science subjects.

\begin{tabular}{|ccccccc}
\hline \multirow{2}{*}{ Statement on Questionnaire } & \multicolumn{2}{c}{ Responses } & \multirow{2}{*}{ Total } & \multicolumn{2}{c}{ Percentage } \\
\cline { 2 - 3 } & Agree (A) & Disagree (D) & & Agree (A) & Disagree (D) \\
\hline $\begin{array}{c}\text { My choice of science subjects is because my } \\
\text { science teachers are very competent and } \\
\text { hardworking }\end{array}$ & 226 & 183 & & 409 & $54 \%$ & $44 \%$ \\
\hline
\end{tabular}

Tables 7-9 show the results of tested hypothesis. The Z-calculation is used with 1.96 as the Z-critical. If the calculated Z-values are lower than the Z-critical, the formulated hypothesis will be accepted or retained. On the other hand, if the calculated Z-value is higher than the Z-critical, the formulated hypothesis will be rejected.

The Z-calculated 2.00 is higher than Z-critical 1.96 therefore rejecting hypothesis as indicated in Table 7.

The calculated $\mathrm{Z}$ is 2.00 , is higher than Z-critical which is 1.96 , hence hypothesis II is rejected since the Z-calculated is higher than the Z-critical as shown in Table 8.

The Z-calculated value is 2.00 , while Z-critical is 1.96 thus hypothesis III is rejected since the Z-calculated is higher than the Z-critical as indicated in Table 9.

\section{Discussion}

Based on the result obtained from the hypothesis testing, we can deduced the following:

The sex of the science teachers does not have any significant influence on the choice of science subjects among females student in Jigawa metropolis

The availability of competent and qualified teachers has a significant influence on the choice of science subjects among female students in Jigawa metropolis

The availability of laboratory equipment/apparatus and practical science activities has an influence on the choice of science subjects among female students in Jigawa metropolis. The importance of trained and competent science teachers is very important because unqualified teachers often contribute towards misleading the students. However, when students are exposed to competent and qualified teachers with effective teaching method, their interest in the science is aroused and sustained. This is very important because one of the problems facing the science teachers is that approach which ranges from what to teach first and how the students should be made to learn. The classroom climate and the method of teaching have significant effect on the type of learning achieved by the students, particularly girls and more likely to be worried by failure to understand and may retreat from difficulty by dropping the subject (Blair, 1980).

Though, the laboratories of the private school sampled were well equipped the students were not adequately exposed to practical science activities because taking the extensive nature of WASSCE/NECO syllabus into consideration. More emphasis is placed on syllabus coverage. The reason that laboratory practical activities are time consuming and if regularly carried out, would make syllabus coverage almost impossible and so they usually resort to doing this practical "once in awhile" laboratory practical was only carried out regularly in SS III and these are usually done during weekend or after class hours.

In the public schools sampled, the science laboratory are of well equipped apart from a syllabus coverage, the science teachers also complained that, laboratory equipment/apparatus are not usually supplied to the schools as at when needed by the controlling boards and even when supplied, they are not adequate for the number of students in the science classes. According to some teachers, the state government only concerned with the science secondary schools. However, the researcher was able to deduce from the science teachers that science students do not carry out practical except one or twice before WASSCE and NECO examination (Douglas, 1975). 
Table 7. It shows the sex of science teachers does not have significant influence on the choice of science subjects.

\begin{tabular}{|c|c|c|c|c|c|}
\hline \multirow{2}{*}{ Statement on Questionnaire } & \multicolumn{2}{|c|}{ Responses } & \multirow{2}{*}{$\begin{array}{c}\text { Total } \\
\text { L }\end{array}$} & \multicolumn{2}{|c|}{ Percentage } \\
\hline & Agree (X1) & Disagree (X2) & & Z-Critical & SD \\
\hline $\begin{array}{l}\text { A. The female science teachers in my school } \\
\text { are very good teachers }\end{array}$ & 188 & 231 & 2.00 & 1.96 & 41.4 \\
\hline $\begin{array}{l}\text { B. In my school there is no female science } \\
\text { teacher }\end{array}$ & 264 & 155 & 2.00 & 1.96 & 41.4 \\
\hline
\end{tabular}

Table 8. It shows the availability of competent and qualified teachers does not have any significant influence on the choice of science subjects.

\begin{tabular}{|c|c|c|c|c|c|}
\hline \multirow{2}{*}{ Statement on Questionnaire } & \multicolumn{2}{|c|}{ Responses } & \multirow{2}{*}{$\begin{array}{c}\text { Total } \\
\text { Critical }\end{array}$} & \multicolumn{2}{|c|}{ Percentage } \\
\hline & Agree (X1) & Disagree (X2) & & Z-Critical & SD \\
\hline $\begin{array}{l}\text { My chose of science subjects is because my } \\
\text { teachers are very competent and hardworking }\end{array}$ & 226 & 183 & 2.00 & 1.96 & 21.5 \\
\hline
\end{tabular}

Table 9. It shows the availability of laboratory equipment do not have any influence on the choice of science subject, among female students.

\begin{tabular}{ccccccc}
\hline \multirow{2}{*}{ Statement on Questionnaire } & \multicolumn{2}{c}{ Responses } & Z-Critical & \multicolumn{2}{c}{ Percentage } \\
\cline { 2 - 5 } & Agree (X1) & Disagree (X2) & & Agree (A) & Disagree (D) \\
\hline $\begin{array}{c}\text { I choose science subjects because the science } \\
\text { laboratories in my school are well equip }\end{array}$ & 274 & 145 & 2.00 & \multirow{2}{*}{1.96} & 64.5 \\
\hline
\end{tabular}

\section{Conclusions and Recommendations}

Science is the nucleus of the technological development and without science there can be no meaningful development. There is a need for more graduate of science in a developing country like Nigeria in respective of their gender. Also there is a great need for more female graduates in field such as medicine, engineering, piloting, radiography etc., this can only be achieved if more female students are encouraged to choose the science subjects. There are some factors that have been militating against the choice of science subjects by female students. For example, Blair (1980) discovered that during adolescent years, there is usually pressure on female gender roles and this discourages them from volunteering for experience work. Nevertheless, it has been indicated that, there is a steady increase in the percentage of young girls offering sciences in secondary schools in Nigeria. In fact, in Jigawa state, there has been an increase of over $60 \%$ of the number of female students offering the sciences at secondary schools level (Barn, 1999).

The data analysis revealed that in the sample school, the choice of a future career has a very great influence on the choice of science among female students in Jigawa metropolis. This is understandable considering the fact that the world is now in the science age where most of the "glamorous" careers are deeply rooted in science and technology. In fact with the application of computer in almost all aspect of life, the world has become science based. Thus, it is necessary to provide teacher with necessary intellectual and professional background which will enhance achieving these specified objectives.

\section{Recommendation}

The researcher wishes to make some general recommendations based on the research findings. Some of the recommendations, would be of benefit to the upliftment of science education in Jigawa and metropolis, Jigawa state Nigeria in general

1) Greater emphasis should be placed on practical science experiment. This is because science by "doing" is the best way to arouse the interest of students in sciences. To this effect:

a) Secondary schools should have well-equipped laboratories which make the conduct of practical easier.

b) Schools should evolved other means of covering the syllabus such as organizing extra classes for the students or using some pre periods for lessons, instead of sacrificing practical periods for lesson in an attempt to cover the syllabus. 
2) The regulating education boards in charge of secondary schools should carry out regular inspection to schools to check qualifications of teachers and qualities of laboratories. This is because there are many schools in the state that do not have will equipped laboratories and qualified teacher especially in the sciences. Where such is discovered, adequate measures should be taken.

3) Science teachers should be encouraged to attend workshops and symposiums on the teaching of science so that there can be a forum for them to come together and share ideas and innovations to make the teaching of sciences and conduct of laboratory practical easier and interesting.

\section{References}

Adejumobi, S. A. (1987). An Investigation into the Subject Preference in Western States of Nigeria Grammar Schools. West Africa Journal of Education, 20.

Adeyemi, J. (1985). The Relationship between Manifest Needs and Choice of Educational Training Programs among Nigeria Collage Students. The Nigeria Journal of Guidance and Counseling, 1.

Akinmuwagun, S. A. (1996). Factors Affecting the Choice of Physics among Female Students in Benin City. Research Project, Benin City: University of Benin.

Barn, A. N. (1979). School Context and Peer Influence on Educational Plans of Adolescent. 145, 7-9.

Blair, G. M. (1980). School Educational Psychology. New York: Mac Milan Publisher.

Compton's Encyclopedia (1988). Heinemann Educational Books. London: Compton's Encyclopedia.

Debay, A. N. et al. (1980). The Sociology of Nigeria Education. London: Mac Milan Press.

Douglas et al. (1975). Culled from the Education. King Re-Educational Research. 3.

Fafunwa, A. B. (1974). Science and Technology Development in Nigeria. A Paper Presented at the 5th Conference of the Science Teachers Association of Nigeria (STAN). Jos: University of Jos. 
Scientific Research Publishing (SCIRP) is one of the largest Open Access journal publishers. It is currently publishing more than 200 open access, online, peer-reviewed journals covering a wide range of academic disciplines. SCIRP serves the worldwide academic communities and contributes to the progress and application of science with its publication.

Other selected journals from SCIRP are listed as below. Submit your manuscript to us via either submit@scirp.org or Online Submission Portal.
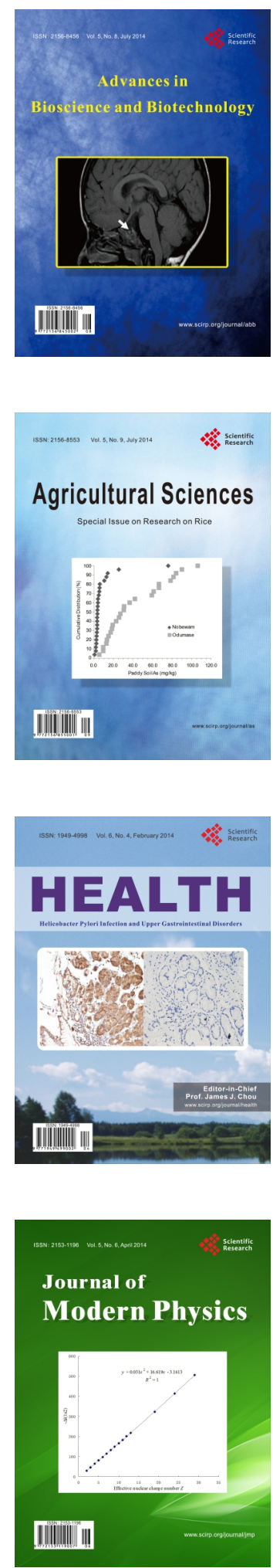
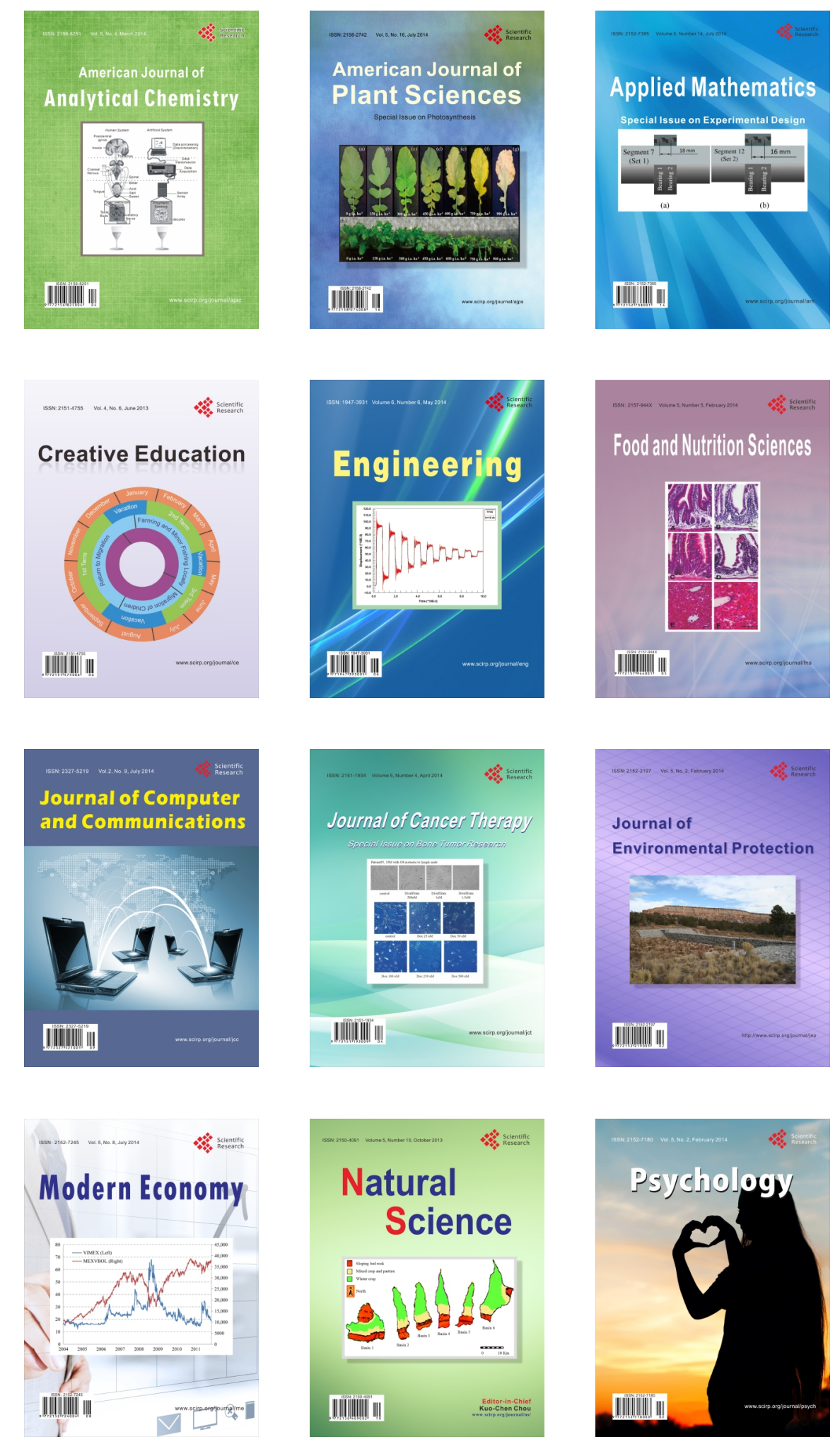